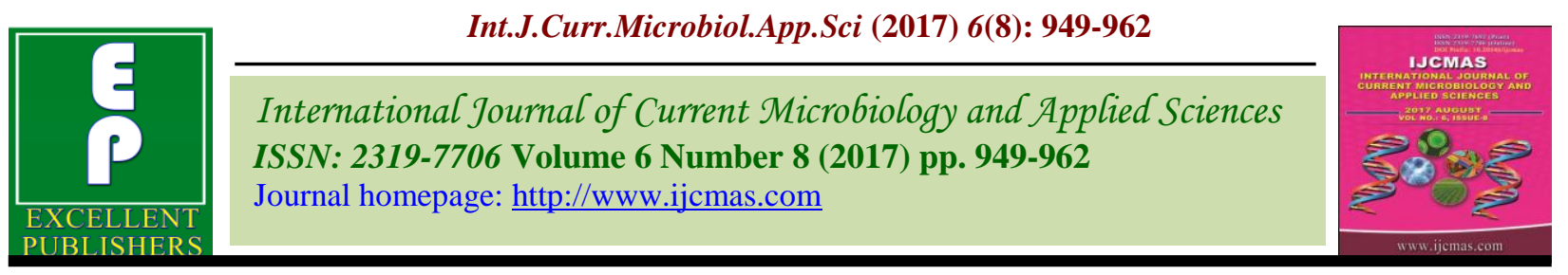

Review Article

https://doi.org/10.20546/ijcmas.2017.608.117

\title{
Perspectives of Breeding for Altering Sunflower Oil Quality to Obtain Novel Oils
}

\author{
Reena Rani, R.K. Sheoran and Bunty Sharma* \\ Department of Genetics and Plant Breeding, CCS Haryana Agricultural University, \\ Hisar, Haryana-125004, India \\ *Corresponding author
}

\begin{tabular}{|c|c|}
\hline & A B S \\
\hline & \multirow{8}{*}{$\begin{array}{l}\text { Sunflower is one of the four most important oilseed crops grown worldwide and the } \\
\text { nutritional quality of its edible oil ranks among the best vegetable oils in cultivation. } \\
\text { Sunflower oil has been traditionally appreciated in the world oil market. However, new } \\
\text { emerging markets are demanding changes in oil quality for both food and non-food } \\
\text { applications. Nutritional and functional properties determining oil quality are primarily } \\
\text { determined by the fatty acid composition of oil. Seed oil content and composition are } \\
\text { determined by genotypic factors and environmental conditions. The variation for oleic acid } \\
\text { content in sunflower oil may be a consequence of location, temperature and rainfall } \\
\text { effects. With adequate location and planting dates, high and mid-oleic hybrids could be } \\
\text { produced with oil that meets the oil quality standards. Genetic variability of the cultivated } \\
\text { sunflower for quality traits may be increased by interspecific hybridization with wild } \\
\text { sunflower species. Induced mutations are also being used to alter the fatty acid } \\
\text { composition of sunflower oil to a significant extent. The existence of (mutant) genes for } \\
\text { increased levels of individual fatty acids and for different forms and levels of tocopherol } \\
\text { enables the development of sunflower hybrids with different oil quality. High-oleic } \\
\text { hybrids with altered tocopherol levels are being developed by mutagenesis, the oil of } \\
\text { which will have } 10-20 \text { times greater oxidative stability than that of conventional sunflower } \\
\text { oil. Common markers associated with different seed-quality traits would be useful in the } \\
\text { marker-assisted selection breeding programme to improve oil quality. The breeding model } \\
\text { of sunflower hybrids should include antioxidant and vitamin parameters balanced for oils } \\
\text { of different applications. }\end{array}$} \\
\hline & \\
\hline & \\
\hline $\begin{array}{l}\text { Genotypic factors } \\
\text { and }\end{array}$ & \\
\hline $\begin{array}{l}\text { Environmental } \\
\text { conditions. }\end{array}$ & \\
\hline Article Info & \\
\hline $\begin{array}{l}\text { Accepted: } \\
\text { 14 June } 2017 \\
\text { Available Online: } \\
10 \text { August } 2017\end{array}$ & \\
\hline & \\
\hline
\end{tabular}

\section{Introduction}

Sunflower (Helianthus annuus L.), belonging to the family 'Asteraceae' is a diploid species $(2 \mathrm{n}=2 \mathrm{x}=34)$. Sunflower is an important oilseed crop and is the preferred source of oil for domestic consumption and cooking worldwide ( $\mathrm{Hu}$ et al., 2010). In the oilseed scenario, sunflower competes with other three major oilseeds, i.e. soyabean, groundnut and rapeseed mustard at global level. Sunflower has a great potential in bridging the gap between the demand and supply of edible oil in future. Sunflower holds great promise because of its short duration, photoinsensitivity, drought tolerance and higher amount of superior quality oil (Anastasi et al., 2010). In addition, due to its large capacity of adaptation to different edaphic and climatic conditions, sunflower is an excellent option for crop rotation. Domesticated sunflower produces a wide range of products, including 
oilseed types (used to produce birdseed or high-quality vegetable oil) and confection seeds for direct human consumption (Kantar et al., 2014). The oil and protein content in sunflower ranges from 35-45 per cent and 1820 per cent, respectively. Sunflower oil is considered as good quality oil from health point of view, due to presence of polyunsaturated fatty acids which are known to reduce the risk of cardiac related problems (Monotti, 2004; Iocca et al., 2016). Additionally, due to the possibility of using its oil as raw material for manufacturing biodiesel, it is arousing the interest of farmers, agriculture professionals and companies in the world. From the nutritional point of view, a diet rich in monounsaturated fatty acids has been suggested to reduce cholesterol in blood plasma, where it lowers low density lipoprotein but not high density lipoprotein (Delpanque, 2000).

\section{Quality components}

\section{Oil quality}

Oil quality in vegetable oils is a relative concept and is determined by the fatty acid composition and the levels of tocopherols, sterols, carotenoids and other compounds. The fatty acid composition of the achene oil determines its end use suitability.

Typically up to $90 \%$ of the fatty acids in conventional sunflower oil are unsaturated, namely oleic (C 18:1, 16\%-19\%) and linoleic (C 18:2, 68\%-72\%) fatty acids whereas palmitic (C 16:0, 6\%), stearic (C 18:0, 5\%), myristic (C 14:0), myristoleic (C 14:1), palmitoleic (C 16:1), arachidic (C 20:0), behenic (C 22:0) and other fatty acids account for the remaining $10 \%$ only (Skoric et al., 2008). Increased levels of these saturated fats are desired for the development of solid or semi-solid fats for the margarine and related industries.
Vegetable oils for human consumption are included in the diet as visible fat (butter, margarine, salad oil and cooking oil) and invisible fat (milk, meat, cheese, pastry, snacks, bread, nuts, etc.). Apart from food uses, large quantities of vegetable oils are directed to non-food applications also. They are used as motor fuels (biodiesel) and lubricants as well as for many applications in the oleochemical industry (detergents, soaps, cosmetics, etc.). Sunflower oil can be used in the manufacture of lacquers, copolymers, polyester films, modified resins and plasticizers. Emulsifiers and surfactants from sunflower oil are used in formulating pesticides (Pryde and Rothfus, 1989). Saturated fatty acids, especially palmitic acid, are regarded as undesirable for human health because they have a detrimental atherogenic effect, mainly by rising serum cholesterol levels as compared with mono- and polyunsaturated fatty acids (Mensink and Katan, 1989). Conversely, oleic and linoleic acids are hypocholesterolemic but oils rich in oleic acid are preferred as it combines a greater oxidative stability and the hypocholesterolemic effect (Mensink and Katan, 1989) than linoleic acid. Sunflower hybrids are often classified according to the potential oleic acid percentage in their oil.

Oleic acid percentage in oil is $10-50 \%$ in traditional hybrids, $50-70 \%$ in mid oleic hybrids and more than $70 \%$ in high oleic hybrids (Sadras and Villalobos, 1996). The high concentration of linoleic acid and very low concentration of linolenic acid mean that it has good drying qualities without the yellowing associated with high-linolenic acid oils (Dorrell and Vick, 1997). Linoleic acid is an essential fatty acid for human beings and it is preferred by industries when oil hydrogenation is required. In addition, with the development of high-oleic sunflower hybrids, sunflower oil has become a more important feedstock for the oleochemical industry, of which the cosmetics industry is a 
major user. Standard sunflower refined oil has a total tocopherol content of around 700 $\mathrm{mg} / \mathrm{kg}$, with about $95 \%$ of the total tocopherols in the alpha-tocopherol form (Fernandez-Martinez et al., 2007). Tocopherol decreases potential risk of chronic diseases in human thereby conferring antioxidant properties to the non-lipid part of oil (Smith et al., 2007). Minor lipids including phytosterols, are present at interesting levels in sunflower $(3,900 \mathrm{mg} / \mathrm{kg})$ (Mouloungui et al., 2006). The phytosterols have potential benefits for human health as they reduce total plasma cholesterol and low density lipoprotein cholesterol (LDL) levels in human beings (Ostlund, 2007; Brufau et al., 2008). Several studies have highlighted other interesting properties of phytosterols such as anti-cancer, anti-inflammatory and anti-oxidation activities (Hansel et al., 2011; Valerio and Awad, 2011). Consequently, these bioactive molecules are now used for various industrial applications and they are also used in nutrition as functional foods (Chen et al., 2008).

\section{Seed storage protein}

Sunflower is considered primarily an oil crop, but following extraction the meal contains around $40 \%$ protein and offers a valuable source of protein for animal and human consumption (Dorrell, 1978). Unfortunately, due to unbalanced amino acid compositions, the values of sunflower proteins are lowered down. The protein of sunflower is hardly lacking in lysine, and has a low intestinal digestibility due to the presence of phenolic compounds, chlorogenic and caffeic acids (Durante et al., 2002).

\section{Breeding objectives}

Breeding programs in sunflower have focused particularly on yield, resistance to diseases and oil quantity and quality (Vear, 2010). Breeding for oil has changed from quantity to quality and the value of seed meal is again becoming economically important. Since the work of Pustovoit, high seed oil content has always been a breeding objective (at least for oilseed sunflower, for confectionary, a low oil content is required). Sunflower oil yield is determined by the product of seed yield per unit area and the oil percentage in the grain. Therefore while breeding for high-oil sunflower varieties and hybrids, consideration of seed yield, oil content and oil quality in seed are important (Vanitha et al., 2014). The development of cultivars with high oil content and high oleic acid concentration is an important breeding objective for this crop due to its nutritional as well as industrial benefits (Flagella et al., 2002). Oil quality is under the control of relatively few genes and is, therefore, amenable to modification by traditional plant breeding and the emerging techniques in biotechnology (Connor and sadras, 1992).

Depending on market demand, some characteristics with respect to oil and protein quality may become major objectives in breeding. High oleic and linoleic acid concentrations are important characteristics in hybrids grown for oil. Recent research has led to the development of high-oleic acid sunflower varieties having more than $89 \%$ oleic acid content in their oils. The high-oleic and mid-oleic sunflower gave high oil content when compared to the traditional varieties (Awatif and Shaker, 2014). By chemical modification, phytosterols could also be used as raw materials in the production of pharmaceuticals as a source of steroids (Van, 2000) or in cosmetics (Folmer, 2003). Overall, the diversification of sterol uses has led to an increase of industrial demands.

\section{Fatty acids}

As the food industry demands fats and oils with a number of specific fatty acid compositions, there is interest in modifying 
the sunflower oil composition at the level of fatty acids and tocopherols in order to provide oils for special purposes to the food and some other industries (biodiesel production) (Skoric et al., 2007). There is an important genetic variation regarding the fatty acid composition of the sunflower oil. The new market requirements regarding the product safety necessitates the resistant oils to high temperatures, less saturated, which resist longer to oxidation (Pacureanu-Joita et al., 2005). One advantage of oil high in oleic acid and the in vitro antioxidants gamma- and/or delta-tocopherols is its higher degree of oxidative stability, which is desirable for frying purposes, refining and storage (Flagella et al., 2002) High-oleic sunflower oil has been evaluated as a potential for biodiesel blend (Moser, 2008).

Applications demanding a high nutritional value of oil (e.g. salad oil) will require a reduction of saturated fatty acids and enhancement of the vitamin $\mathrm{E}$ (alphatocopherol) content of the oil. Research is mainly focused on (i) the production of more stable sunflower oils for biolubrication and (ii) the increase of healthy substitutes for food industry (Kumar et al., 2013).

It is possible to combine certain contents of palmitic, stearic (Mancha et al., 1994), oleic and linoleic acids with desirable tocopherol composition by breeding. Thus, lines of different types of sunflower oil can be obtained for edible and non-edible uses. A hybrid with both high oleic and high tocopherol content in seeds can produce an edible oil with long shelf life. High content of strong antioxidants, such as $\beta$-, $\gamma$-, and $\delta$ tocopherols increased oil oxidative stability of linoleic and oleic types of oil by 1.2-3.0 times. The breeding model of sunflower hybrids should include antioxidant and vitamin parameters balanced for oils of different applications (Demurin et al., 1996).
Near infrared reflectance spectroscopy (NIRS) is very versatile and a multi trait technique of large application in the analysis of quality characteristics in food and agricultural commodities (Batten, 1998).

\section{Protein content and hullability}

There is generally a negative correlation between oil and protein contents. But a little research on the genetics of protein content as compared to that of oil content has been carried out recently. The alternative method to increase the protein content in seed meal is to hull seed. Recently, there is renewed interest in this aspect, since hulled sunflower meal would be good alternative protein source to replace imported soybean and hulls are now an economic fuel (Dauguet et al., 2015). In addition to total protein concentration, it is important to direct breeding programs toward increasing certain protein fractions. Fernandez-Martinez and Alba (1984) suggest that the ratio of albumins to globulins can be a criterion of selection for sunflower protein quality, and can be modified by selection. The amino acid composition of protein may be another important criterion in the selection for quality. Bedov and Skoric (1981) stated that increases in protein concentration can simultaneously increase lysine and most amino acids. Another important problem in sunflower breeding for protein quality is the elimination of chlorogenic acid.

Hullability is correlated positively with hull content $\left(\mathrm{r}=0.35^{*}\right.$ to $\left.0.69^{*}\right)$ but negatively with oil content $\left(\mathrm{r}=-0.34^{*}\right.$ to- $\left.0.71^{* * *}\right)$. Inbreds and hybrids producing achenes with high oil content and quite small hull content but a good hullability are the most promising for improvement of the quality of sunflower seed meal. Such genotypes are rare so that a recurrent selection programme is recommended to increase the frequency of favorable genes (Denis and Vear, 1996). In 
high protein varieties and hybrids, high yield and high protein concentration and quality would be important.

\section{Effect of Environmental Factors}

Seed oil content and composition are complex traits that are determined by genotypic factors and environmental conditions (Izquierdo and Aguirrezabal, 2008; Baydar and Erbas, 2005; Roche et al., 2006). The instability of most genotypes across environments may be a consequence of (1) the planting location, (2) planting date that resulted in different temperatures during the maturation stages, (3) high or low rainfall occurring during the growing season and (4) the presence of modifier genes in the genetic backgrounds of the genotypes that made them more sensitive to environmental influences. Environmental factors contributed the most to variability in oil content, while genotypic factors contributed the most to variability in fatty acid content (Merwe et al., 2013).

Water stress conditions occurring during the seed-filling period resulted in an increase in the oleic to linoleic ratio (Baldini et al., 2002) while no effect on oleic/linoleic ratio was observed by Salera and Baldini (1998). Genotypes exhibited different sensitivity to environmental conditions and high oleic acid genotypes seemed to be more stable than traditional sunflower cultivars regarding fatty acid composition (Laureti and Del Gatto, 2000; Piva et al., 2000). As for the oil fatty acid composition, the main effects of early sowing were a decrease in oleic acid and a consistent increase in linoleic acid (Flagella $e t$ al., 2002). Temperature has been reported to have a minor effect on the oleic acid content of high oleic hybrids with respect to standard ones (Lagravere et al., 2000). Oil concentration in seed being a quantitative trait depends on mean daily temperatures and available moisture at the seed filling stage, as well as on the duration of stage itself. The accumulation of oil in seed is intensified by mean daily temperature below $25^{\circ} \mathrm{C}$, sufficient soil moisture, and an absence of diseases. High temperatures especially night temperatures and low rainfall during the seedfilling stages leads to a decrease in oil content (linoleic acid) and increase in oleic acid content (Sheoran, 2016). A better understanding of genotype and environmental effects on fatty acid composition is needed to further improve oil quality.

Sunflower oil contains a considerable amount of linoleic acid (550-650 g/kg) and a good quantity of oleic acid (200-300 g/ $/ \mathrm{kg})$. The ratio of the main fatty acids (oleic and linoleic acid) will change during oil forming. Specifically, the concentration of linoleic acid increases until the end of seed maturation whereas the concentration of oleic acid decreases, due to desaturation of linoleic to oleic acid (Skoric, 1992).

\section{Use of Wild Species}

Recent emphasis on the concentration and fatty acid composition of sunflower oil has increased interest in using wild species in breeding programs to enhance oleic or linoleic acid, or to reduce saturated fatty acids. For increasing the oil content in seed, own and foreign hybrids, hybrids developed through distant hybridization and new mutant forms are used as sources of high oil content (Nikolova and Christov, 1996). Sunflower lines with high oil content were derived from crosses with the wild species $H$. eggertii, $H$. pauciflorus, $H$. smithii, $H$. hirsutus, $H$. annuus, $H$. nuttallii ssp. rydbergii, $H$. pumilus, etc. (Christov, 2012). H. deserticola (desert sunflower) and $H$. anomalus (sand sunflower) are excellent candidates for oil concentration and quality improvement. The $H$. deserticola population had an oil concentration of $330 \mathrm{~g} / \mathrm{kg}$, whereas the $H$. 
anomalus populations had very high oil concentrations, 430 and $460 \mathrm{~g} / \mathrm{kg}$, the highest ever reported in any wild sunflower species. Wild annual $H$. annuus and $H$. petiolaris are two of the closest progenitors of cultivated sunflower. All these four wild annual species have the same chromosome number $(n=17)$ as cultivated sunflower, facilitating the introgression of traits into cultivated sunflower (Seiler, 2007).

The introgression of wild species into cultivated sunflower with different fatty acid profiles and a stable linoleic concentration could facilitate the expansion of commercial sunflower production into the southern latitudes and increases the available genetic diversity for improving cultivated sunflower (Seiler et al., 2010).

Helianthus niveus spp. canescens had an oil concentration of $402 \mathrm{~g} / \mathrm{kg}$. Several wild species of Helianthus had one or more populations having linoleic acid concentration above $720 \mathrm{~g} / \mathrm{kg}$ with a range for the genus from $370 \mathrm{~g} / \mathrm{kg}$ in one population of $H$. argophyllus to $830 \mathrm{~g} / \mathrm{kg}$ in $H$. porteri. The lower saturated fatty acid profile and the high linoleic concentration in the oil of $H$. porteri indicate that this species has the potential to reduce saturated fatty acids and increase linoleic acid concentration in traditional commercial sunflower oil. Oleic acid, another important fatty acid, appears to be quite variable in wild sunflower species. Several species had oleic concentrations of $400 \mathrm{~g} / \mathrm{kg}$ and greater (Seiler, 1992).

\section{Protein content}

In commercial sunflower meal, protein content is approximately $440 \mathrm{~g} / \mathrm{kg}$ (dehulled) and $280 \mathrm{~g} / \mathrm{kg}$ (whole seeds) (Doty, 1978). Sufficient variability exists in the wild Helianthus species to be useful in breeding programs with an objective to increase protein concentration in the seed. In any breeding work for increased protein content, it would be necessary to maintain or improve the balance of essential amino acids. This may be more crucial than increasing the percentage of crude protein. Defatted kernels of $H$. pauciflorus, are reported to contain $710 \mathrm{~g} / \mathrm{kg}$ protein (Georgieva-Todorova and Hristova, 1975).

\section{Effect of Mutations}

Sunflower is regarded as one of the most promising crops when it comes to the genetic alteration of oil quality (Scharp, 1986). Mutants affecting seed oil fatty acid composition are very useful for getting novel oil composition (Lacombe and Berville, 2000). The existence of (mutant) genes for increased levels of individual fatty acids and for different forms and levels of tocopherol enables the development of sunflower hybrids with altered oil quality and composition (Skoric et al., 2008). The greatest progress using mutants has been made in developing high-oleic hybrids (>90\% oleic acid). The first artificial mutation to have a favourable effect was significant alteration of sunflower oil carried out by Soldatov (1976), who treated the seed of the cultivar VNIIMK 8931 with a $2.5 \%$ solution of dimethyl sulphate (DMS) to obtain an induced mutation for a high oleic acid content, which by further selection over generations produced plants containing 800-900 g/kg oleic acid in the oil which eventually were used to develop the high-oleic variety, Pervenets. Sunflower breeders have since used this cultivar worldwide as the source of genes for developing the present-day high-oleic hybrids (Skoric et al., 2007).

There has been considerable work done recently on the development of high-oleic hybrids with altered tocopherol levels, the oil of which will have 10-20 times greater 
oxidative stability than that of conventional sunflower oil.

While sunflower breeders work on developing hybrids with altered oil quality, medical scientists and nutritionists in particular will determine the parameters for the use of these novel types of oil that can improve human nutrition and be used in the prevention of cardiovascular diseases (Skoric et al., 2008).

Treating sunflower seeds with $\gamma$ - and X-rays has produced mutants with 25\%-30\% palmitic acid. Sunflower seed treatment with X-rays has also resulted in mutants having $30 \%$ palmitoleic acid, while treatments with mutagenic sodium azide have produced seeds containing $35 \%$ stearic acid. Mutants have also been obtained that have a high linoleic acid content $(>80 \%)$ by treating seeds with $\mathrm{X}$ rays and ethyl methanesulfonate. Spontaneous mutations controlled by recessive genes have been discovered that significantly alter tocopherol forms and levels.

Mutagenesis was also effective for developing mutants with altered fatty acid content like the high oleic acid mutant "Pervenets" (Soldatov, 1976); mutants $275 \mathrm{HP}$ and CAS-5 with high palmitic acid content (Osorio et al., 1995), CAS-12 with high palmitic acid and increased oleic acid content (Fernandez-Martinez et al., 1997) and CAS-37 with high palmitic acid and medium content of palmitoleic acid (Salas et al., 2004); mutants CAS-8, CAS-4 and CAS-3 with medium to high stearic acid content (Osorio et al., 1995) and CAS-14 with very high stearic acid content (FernandezMoya et al., 2002); two mutants with low stearic acid content LS-1 and LS-2 and one mutant LP-1 with low palmitic acid content (Miller and Vick, 1999). The mutants IAST-1 and IAST-540 with increased levels of gamma tocopherol (>95\%) were developed by Mutagenesis (Velasco et al., 2004).

\section{Seed storage protein}

The in vitro mutagenesis of seed storage protein genes to increase the content of high valuable amino acids and/or the introduction of heterologous genes encoding proteins containing high lysine can allow to improve the nutritive value of the sunflower seeds (Durante et al., 2002). During the last 30 years these components have been extensively modified in sunflower through conventional selection from naturally occurring variation and through mutagenesis.

As a result, together with the standard sunflower oil, there is currently available a vast diversity of other sunflower oil types, for example low saturated $(<7 \%)$, high palmitic $(>25 \%)$, high stearic $(>25 \%)$, high oleic $(>85 \%)$, high linoleic $(>75 \%)$ as well as a number of oils with intermediate levels and combinations among them. Similarly, the standard sunflower oil with $95 \%$ of the tocopherols in the alpha-tocopherol form has been modified to produce oils with high levels of beta-tocopherol (>75\%), gammatocopherol (>95\%), and delta-tocopherol $(>65 \%)$. The novel fatty acid and tocopherol traits are in all cases governed by a reduced number of genes, which facilitates considerably their management in plant breeding programs aimed at developing cultivars with improved oil quality.

\section{Genetic basis of improvement}

Interrelationships among fatty acid concentrations should also be taken into consideration in breeding for genetic improvement of quality traits of sunflower. There is a significant positive association $(r=$ 0.561 ) between palmitic and stearic acid and a strong negative association ( $\mathrm{r}=-0.989)$ between oleic and linoleic acid in the wild sunflower (Seiler, 1985b). Both oleic and linoleic fatty acids also show some 
association with stearic acid, so the selection for either of these may affect the level of stearic acid. The association of palmitic acid with linoleic acid and oleic acid is nonsignificant hence, breeding or selection for these acids should not affect palmitic acid.

Three genes are involved in the control of high levels of each of palmitic $(P 1, P 2$, and $P 3)$ and stearic acid content (Es1, Es2, Es3) and one or two genes in the control of low levels of these fatty acids. One principal gene Ol1 and several modifier genes are involved in the control of high oleic acid content. Molecular markers linked the major high oleic genes that are reliable for maker assisted selection has been developed (Schuppert et al., 2006). Similarly, two unlinked genes, Tph1 and Tph2, control altered tocopherol composition (Fernandez-Martinez et al., 2007). In high-oleic sunflower, several major and minor genes are involved in increased oleic acid concentration and its stability (Fernandez-Martınez et al., 2004). Modifying genes that affect oleic acid content have also been characterised.

The incorporation of the genes for oil quality into highly productive lines and hybrids using molecular markers will enable sunflower breeders to increase the competitiveness of the sunflower relative to other field crops (Skoric et al., 2007). Nevertheless, candidate genes from the fatty acids biosynthetic pathway have been recently mapped using molecular markers (Hongtrakul et al., 1998; Lacombe et al., 2000; Perez-Vich et al., 2000b; Lacombe and Berville, 2001) that can serve as starting point for chromosome walking or chromosome landing to clone the corresponding gene. The modification by genetic transformation of fatty acids composition of sunflower seed oil can also be prospected in a near future. To address the needs of the confectionery industry for saturated fatty acids, high stearic acid content oils have been developed mainly by genetic modification of the FatA stearoyl-ACP thioesterase and the SAD stearoyl-ACP desaturase (Kumar et al., 2013). Additive type of gene action controls the traits oleic acid content and linoleic acid content. Two potential QTLs for oleic acid as well as linoleic acid content have been identified with the markers ORS 762 and HO_Fsp_b which explained more than 57.6-66.6\% of phenotypic variation. Hence it can be concluded that these markers/QTLs would be useful in the marker-assisted selection breeding programme to improve oil quality (Premnath et al., 2016). Moreover, molecular markers for some of the traits have been developed in recent years, for example for high stearic and high oleic acid contents (Perez- Vich et al., 2002c), or high beta- and gamma-tocopherol contents (Vera-Ruiz et al., 2006; Garcia-Moreno et al., 2006). The use of these molecular markers will contribute to improve breeding efficiency.

Marker assisted backcross is routinely applied for the introgression of desired gene in plant breeding programmes. Phenotypic methods require quantification of oleic acid content on sunflower seeds using gas chromatography which is time consuming and environmentally affected.

Marker assisted backcross was carried out for the effective transfer of the high oleic gene from potential donor inbred, $\mathrm{HO}$ 5-13 to recipient parents, COSF 7B and CSFI 99. Polymorphic markers were used to apply foreground and background selection respectively in backcrosses between a high oleic donor and two low oleic recurrent parents. In $\mathrm{BC}_{4} \mathrm{~F}_{1}$ generation, one high oleic plant in each cross were identified that possessed recurrent parent genome (>97\%) with $\mathrm{OD}-\mathrm{HO}$ (oleate-desaturase high oleic) allele. Phenotypic analysis of oleic and linoleic acid content was conducted using 
near infrared reflectance spectroscopy (NIRS) which revealed oleic acid composition of 80.47 to $85.42 \%$ in sunflower seeds. Thus marker assisted backcross approach serves the purpose of efficient transfer of high oleic gene into elite sunflower inbreds which infers sustainable saving in time compared to conventional backcross breeding (Premnath et al., 2014).

In conclusion, a wide range of sunflower lines with contrasting fatty acids profiles have been developed, for example with mid and high levels of oleic acid, high and low levels of saturated fatty acids, high concentration of linoleic acid, as well as different ranges of intermediate levels of the different fatty acids and combinations among them. Similarly, lines with high levels of beta-, gamma-, and delta-tocopherol have been developed providing more variability for tocopherol profiles in sunflower oil.

The combination of several quality traits in a single phenotype will enable the tailoring of specialty oils for specific uses in the food and non-food industry. The novel fatty acids and tocopherol traits are in all cases governed by a reduced number of genes and can be easily managed in breeding programs aimed at developing cultivars incorporating these traits.

However, new emerging markets together with high concern about health risks of foods and an increasing request of vegetable oils for specific non-food uses are demanding changes in oil quality. As in other vegetable oils, the objective of modifying sunflower seed oil quality has been to develop oils with enhanced nutritional and functional properties and oils that require little, if any, processing for specific end-use markets. The possibility of tailoring different specialty oils for food and non-food applications guarantees a promising future to sunflower in the global world market.

\section{References}

Anastasi, U., Cammarata, M., Guiffre, A.M., Gresta, F. and Abbate, V. 2010. Yield performance and grain lipid composition of standard and oleic sunflower as affected by water supply. Field Crops Research, 119: 145-153.

Awatif, I.I. and Shaker, M.A. 2014. Quality characteristics of high-oleic sunflower oil extracted from some hybrids cultivated under Egyptian conditions. HELIA, 37(60): 113-126.

Baldini, M., Giovanardi, R., TahmasebiEnferadi, S. and Vannozzi, G.P. 2002. Effects of water regime on fatty acid accumulation and final fatty acid composition in the oil of standard and high oleic sunflower hybrids. Italian Journal of Agronomy, 6: 119-126.

Batten, G.D. 1998. Plant analysis using near infrared reflectance spectroscopy: the potential and the limitations. Australian Journal of Experimental Agriculture, 38: 697-706.

Baydar, H. and Erbas, S. 2005. Influence of seed development and seed position on oil, fatty acids and total tocopherol contents in sunflower (Helianthus annuus L.). Turkish Journal of Agriculture and Forestry, 29: 179-186.

Bedov, S. and Skoric, D. 1981. Possibilities of increasing protein content in sunflower. In: Proc. EUCARPIA: Sunflower Breeding, Prague, Czechoslovakia, pp. 267-278.

Brufau, G., Canela, M.A. and Rafecas, M. 2008. Phytosterols: physiologic and metabolic aspects related to cholesterollowering proprieties. Nutrition Research, 28: 217-225.

Chen, Y.Z., Jiao, R. and Ma, K.Y. 2008. Cholesterol-lowering nutraceuticals and functional foods. Journal of Agricultural and Food Chemistry, 56: 8761-8773. 
Christov, M. 2012. Contribution of interspecific hybridization to sunflower breeding. Helia, 35(57): 37-46.

Connor, D.J. and Sadras, V.O. 1992. Physiology of yield expression in sunflower. Field crops research, 30: 333-389.

Dauguet, S., Fine, F., Guillemain, C., Carre, P., Merrien, A., Krouti, M. and Champolivier, L. 2015. Impact of pedoclimatic and agricultural conditions on sunflower seeds characteristics in relation to the dehulling process. Oilseeds \& fats Crops and Lipids, 22(4) D402: 1-5.

Delpanque, B. 2000. Nutritional value of sunflowers. In: Proceedings of XV International Sunflower Conference, Toulouse, and Plenary B- pp. 15-16.

Demurin, Y., Skoric, D. and Karlovic, D. 1996. Genetic variability of tocopherol composition in sunflower seeds as a basis of breeding for improved oil quality. Plant Breeding, 115: 33-36.

Denis, L. and Vear, F. 1996. Variation of hullability and other seed characteristics among sunflower lines and hybrids. Euphytica, 87(3): 177-187.

Dorrell, D.G. 1978. Processing and utilization of oilseed sunflower. In: Carter, J.F. (Ed.), Sunflower Science and Technology. Crop Science. Society of America, Madison, WI, USA, pp. 407436.

Dorrell, D.G. and Vick, B.A. 1997. Properties and processing of oilseed sunflower. In: Schneiter, A.A. (Ed.), Sunflower Technology and Production. Crop Science Society of America, Madison, WI, USA, pp. 709-745.

Doty, H.O. 1978. Future of sunflower as an economic crop in North America and the world. In: J.F. Carter (Editor), Sunflower Science and Technology, Agronomy Monograph No. 19. American Society of Agronomy,
Madison, WI, pp. 457-488.

Durante, M., Vannozzi, G.P., Pugliesi, C. and Bernardi, R. 2002. The role of biotechnologies in the development of sunflower cultures in the world. HELIA, 25, Nr. 36, pp. 1-28.

Fernandez-Martinez, J. and Alba, E. 1984. Breeding for oil and meal quality in sunflower. In: Proc. Int. Symp. on Science and Bio-Technology for an Integral Sunflower Utilisation, Bari, Italy, pp. 75-97.

Fernandez-Martinez, J.M., Osorio, J., Mancha, M., and Garces, R. 1997. Isolation of high palmitic mutants on high oleic background. Euphytica, 97: 113-116.

Fernandez-Martinez, J.M., Perez-Vich, B., Velasco, L. and Dominguez, J. 2007. Breeding for specialty oil types in sunflower. HELIA, 30(46): 75-84.

Fernandez-Martinez, J.M., Velasco, L. and Perez-Vich, B. 2004. Progress in the genetic modification of sunflower oil quality. In: Proceedings of $16^{\text {th }}$ International Sunflower Conference, Fargo, ND, and pp. 1-14.

Fernandez-Moya, V., Martinez-Force, E. and Garces, R. 2002. Temperature effect on a high stearic acid sunflower mutant. Phytochemistry, 59:33-38.

Flagella, Z., Rotunno, T., Tarantino, E., Caterina, R.D. and Caro, A.D. 2002. Changes in seed yield and oil fatty acid composition of high oleic sunflower (Helianthus annuus L.) hybrids in relation to the sowing date and the water regime. European Journal of Agronomy, 17: 221-230.

Folmer, B.M. 2003. Sterol surfactants: from synthesis to applications. Advances in Colloid and Interface Science, 103: 99109.

Garcia-Moreno, M.J., Vera-Ruiz, E.M., Fernandez-Martinez, J.M., Velasco, L. and Perez-Vich, B. 2006. Genetic and 
molecular analysis of high gammatocopherol content in sunflower. Crop Science, 46(5).

Georgieva-Todorova, J. and Hristova, A. 1975. Studies on several wild-growing Helianthus species. C.R. Acad. Agricole Georgi Dimitrov, 8(4): 51-55.

Hansel, B., Courie, R., Bayet, Y., Delestre, F. and Bruckert, E. 2011. Phytosterols and atherosclerosis. Revue de Medecine Interne, 32: 124-129.

Hongtrakul, V., Slabaugh, M.B. and Knapp, S.J. 1998. DFLP, SSCP, and SSR markers for $\Delta 9$-stearoyl-acyl carrier protein desaturases strongly expressed in developing seeds of sunflower: intron lengths are hypervariable among inbred lines. Molecular Breeding, 4: 195-203.

Hu, J., Seiler, G. and Kole, C. 2010. Genetics, genomics and breeding of sunflower. Routledge, USA, pp. 342.

Iocca, A.F.S., Dalchiavon, F.C., Malacarne, B.J. and Carvalho. C.G.P.C. 2016. Content and oil productivity in sunflower genotypes produced in campo novo do parecis - Mt, Brazil. $19^{\text {th }}$ International Sunflower Conference, Edirne, Turkey. pp. 1136-1141.

Izquierdo, N. and Aguirrezabal, L. 2008. Genetic variability in the response of fatty acid composition to night temperature during grain filling in sunflower. Field Crops Research, 106: 116-125.

Kantar, M.B., Betts, K., Michno, J.M., Luby, J.J., Morrell, P.L., Hulke, B.S., Stupar, R.M. and Wyse, D.L. 2014. Evaluating an interspecific Helianthus annuus $\times$ Helianthus tuberosus population for use in a perennial sunflower breeding program. Field Crops Research, 155: 254-264.

Kumar, A.P.K., Boualem, A., Bhattacharya, A., Parikh, S., Desai, N., Zambelli, A., Leon, A., Chatterjee, M. and Bendahmane, A. 2013. SMART -
Sunflower Mutant population and Reverse genetic Tool for crop improvement. BMC Plant Biology, 13: 38.

Lacombe, S. and Berville, A. 2000. Problems and goals in studying oil composition variation in sunflower. In: Proceedings of the $15^{\text {th }}$ International Sunflower Conference, 12-15 June 2000. Toulouse, France, pp. PLD16-PLD25.

Lacombe, S. and Berville, A. 2001. Comparison of one oleate desaturase genomic region in the $\mathrm{LO}$ and high oleic sunflower mutant: a model that explains the Pervenets mutation. In: Proceedings of the 5th European Conference on Sunflower Biotechnology, November 4-8, 2001, San Giuliano Terme, Italy, and pp. 42.

Lacombe, S., Guillot, H., Kaan, F., Millet, C. and Berville, A. 2000. Genetic and molecular characterization of the high oleic content of sunflower oil in Pervenets. In: Proceedings of the $15^{\text {th }}$ International Sunflower Conference, 1215 June 2000. Toulouse, France, pp. A13-A18.

Lagravere, T., Champolivier, L., Lacombe, S., Kleiber, D., Berville, A. and Dayde, J. 2000. Effects of temperature variations on fatty acid composition in sunflower oil (Helianthus annuus L.) hybrids. In: Proceedings of the 15th international sunflower conference, Toulouse, pp. A73-A78.

Laureti, D. and Del Gatto, A. 2000. Genotype $\mathrm{x}$ environment interaction in new sunflower (Helianthus annuus L.) hybrids. In: Proceedings of the $15^{\text {th }}$ international sunflower conference, Toulouse, E IT 14.

Mancha, M., Osorio, J., Garces, R., Ruso, J., Munoz, J. and Fernandez-Martinez, J. 1994. New sunflower mutants with altered seed fatty acid composition. Progress in Lipid Research, 33: 147- 
154.

Mensink, R.P., and Katan, M.B. 1989. Effect of a diet enriched with monounsaturated or polyunsaturated fatty acids on levels of low-density and high-density lipoprotein cholesterol in healthy women and men. The New England Journal of Medicine, 321: 436-441.

Merwe, R.V.D., Labuschagne, M. T., Herselman, L. and Hugo, A. 2013. Stability of seed oil quality traits in high and mid-oleic acid sunflower hybrids. Euphytica, 193: 157-168.

Miller, J.F. and Vick, B.A. 1999. Inheritance of reduced stearic and palmitic acid content in sunflower seed oil. Crop Science, 39: 364-367.

Monotti, M. 2004. Growing non-food sunflower in dry land conditions. Italian Journal of Agronomy, 8: 3-8.

Moser, B. 2008. Influence of blending canola, palm, soybean, and sunflower oil methyl esters on fuel properties of biodiesel. Energy Fuels, 22: 43014306.

Mouloungui, Z., Roche, J. and Bouniols, A. 2006. Extractive limitations of native functional ingredients: bioactive lipids by chemical modifications. Oilseeds \& fats Crops and Lipids, 13(1): 16-22.

Nikolova, L. and Christov, M. 1996. Investigations on hybrid combinations between cultivated sunflower and the wild species $H$. neglectus, $H$. giganteus, $H$. decapetalus and $H$. strumosus. In: Proceedings of International Sunflower Confererence, Beijing/ Shenyang, China, 1021-1028.

Osorio, J., Fernandez-Martinez, J.M., Mancha, M. and Garces, R. 1995. Mutant sunflower with high concentration in saturated fatty acid in the oil. Crop Science, 35: 739-742.

Ostlund, RE Jr. 2007. Phytosterols, cholesterol absorption and healthy diets. Lipids, 42: 41-44.
Pacureanu-Joita, M., Stanciu, D., Petcu, E., Raranciuc, S. and Sorega., I. 2005. Sunflower genotypes with high oleic acid content. Romanian agricultural research, 22: 23-26.

Perez-Vich, B., Fernandez-Martinez, J.M., Grondona, M., Knapp, S.J. and Berry, S.T. 2002c. Stearoyl-ACP and oleoylPC desaturase genes cosegregate with quantitative trait loci underlying stearic and oleic acid mutant phenotypes in sunflower. Theoretical and Applied Genetics, 104: 338-349.

Perez-Vich, B., Fernandez-Martinez, J.M., Munoz-Ruz, J., Knapp, S.J. and Berry, S.T. 2000b. Progress in the development of DNA-based markers for high stearic acid content in sunflower. In: Proceedings of the $15^{\text {th }}$ International Sunflower Conference, 12-15 June 2000. Toulouse, France, pp. A49-A54.

Piva, G., Bouniols, A. and Mondies, M. 2000. Effect of cultural conditions on yield, oil content and fatty acid composition of sunflower kernel. In: Proceedings of the $15^{\text {th }}$ international sunflower conference, Toulouse, France, pp. A61-A66.

Premnath, A., Manivannan, N., Chandirakala, R., Kuppusamy, S. and Vanniarajan, C. 2016. Mapping quantitative trait loci controlling oil content, oleic acid and linoleic acid content in sunflower (Helianthus Annuus L.). Molecular Breeding: New Strategies in Plant Improvement, 36(7): 1-7.

Premnath, A., Manivannan, N., Chandirakala, R. and Vanniarajan, C. 2014. Marker assisted backcross approach for enhanced oleic acid content in sunflower (Helianthus annuus L.). National Seminar on Challenges and Innovative Approaches in Crop Improvement, December 16 \& 17, AC \& RI, Madurai, TNAU, India, pp. 194195.

Pryde, E.H. and Rothfus, J.A. 1989. Industrial 
and non-food uses of vegetable oils. In: Robbelen, G., Downey, R.K., Ashri, A. (Eds.), Oil Crops of theWorld: Their Breeding and Utilization. McGraw-Hill, NY, USA, pp. 87-117.

Roche, J., Bouniols, A., Mouloungui, Z., Barranco, T. and Cerny, M. 2006. Management of environmental crop conditions to produce useful sunflower oil components. European Journal of Lipid Science and Technology, 108: 287-297.

Sadras, V. and Villalobos, F. 1996. Physiological characteristics related to yield improvement in sunflower (Helianthus annuus L.). In: G. Slafer (Ed.), Genetic Improvement of Field Crops. Marcel Dekker, New York, pp. 287-320.

Salas, J.J., Martinez-Force, E. and Garces, R. 2004. Biochemical characterization of a high palmitoleic acid Helianthus annuus mutant. Plant Physiology and Biochemistry, 42: 373-381.

Salera, E. and Baldini, M. 1998. Performance of high and low oleic acid hybrids of sunflower under different environmental conditions. Helia, 21: $55-67$.

Scharp, W.R. 1986. Opportunities for biotechnology in the development of new edible vegetable oil products. Journal of the American Oil Chemists' Society, 63(5): 594-600.

Schuppert, G.F., Tang,.S, Slabaugh, M.B and Knapp, S.J. 2006. The sunflower higholeic mutant $\mathrm{Ol}$ carries variable tandem repeats of FAD2-1, a seed specific oleoyl-phosphatidyl choline desaturase. Molecular Breeding, 17: 214-256.

Seiler, G.J., Gulya, T.J. and Kong, G. 2010. Oil concentration and fatty acid profile of wild Helianthus species from the southeastern United States. Industrial Crops and Products, 31: 527-533.

Seiler, G.J. 1985b. Interrelation of fatty acids in oil of wild annual sunflower (Helianthus annuus L.). In: Proceedings of $11^{\text {th }}$ International Sunflower Conference, Mar del Plata, Argentina. Int. Sunflower Assoc., Toowoomba, Australia, pp. 529-534.

Seiler, G.J. 1992. Utilisation of wild sunflower species for the improvement of cultivated sunflower. Field crops research, 30: 195-230.

Seiler, G.J. 2007. Wild annual Helianthus anomalus and $H$. deserticola for improving oil content and quality in sunflower. Industrial Crops and Products, 25: 95-100.

Sheoran, R.K. 2016. Perspective and challenges to develop high yielding, disease resistant and oil quality sunflower hybrids in India. $19^{\text {th }}$ International Sunflower Conference, Edirne, Turkey, pp. 324-330.

Skoric, D. 1992. Achievements and Future Directions of Sunflower Breeding, Field Crops Research. 30(3-4): 231-270.

Skoric, D., Jocic, S., Hladni, N and Vannozzi, G.P. 2007. An analysis of heterotic potential for agronomically important traits in sunflower (Helianthus annuus L.). HELIA, 30(46): 55-74.

Skoric, D., Jocic, S., Lecic, N. and Sakac, Z. 2007. Development of sunflower hybrids with different oil quality. HELIA, 30(47): 205-212.

Skoric, D., Jocic, S., Sakac, Z. and Lecic, N. 2008. Genetic possibilities for altering sunflower oil quality to obtain novel oils. Canadian Journal of Physiology and Pharmacology, 86(4): 215-221.

Smith, S.A., King, R.E. and Min, D.B. 2007. Oxidative and thermal stabilities of genetically modified high oleic sunflower oil. Food Chemistry, 102: 1208-1213.

Soldatov, K.J. 1976. Chemical mutagenesis for sunflower breeding. In: Proceedings of $7^{\text {th }} \quad$ International Sunflower 
Conference, Krasnodar, Russia. pp. 352-357.

Valerio, M. and Awad, A.B. 2011. $\beta$ sitosterol down-regulates some proinflammatory signal pathways by increasing the activity of tyrosine phosphatase SHP-1 in J774A.1 murine macrophages. International Immunopharmacology, 11(8): 1012-17.

Van Dansik P. 2000. Phytosterols. In: Proceedings of the final conference CTVO-net, Bonn (Germany), pp. 149180.

Vanitha, J., Manivannan, N. and Chandirakala, R. 2014. Quantitative trait loci analysis for seed yield and component traits in sunflower. African Journal of Biotechnology, 13(6): 754761.
Vear, F. 2010. Classic genetics and breeding. In: $\mathrm{Hu} \mathrm{J}$, Seiler G, Kole C (Eds.) Genetics, genomics and breeding of sunflower. Science Publishers Inc. Jersey, pp. 51-77.

Velasco, L., Perez-Vich, B. and FernandezMartinez, J.M. 2004. Novel variation for tocopherol profile in sunflower created by mutagenesis and recombination. Plant Breeding, 123: 490- 492.

Vera-Ruiz, E.M., Velasco, L., Leon, A.J., Fernandez-Martnez, J.M. and PerezVich, B. 2006. Molecular tagging and genetic mapping of the Thpl gene controlling beta-tocopherol accumulation in sunflower. Molecular Breeding, 17: 291-296.

\section{How to cite this article:}

Reena Rani, R.K. Sheoran and Bunty Sharma. 2017. Perspectives of Breeding for Altering Sunflower Oil Quality to Obtain Novel Oils. Int.J.Curr.Microbiol.App.Sci. 6(8): 949-962. doi: https://doi.org/10.20546/ijcmas.2017.608.117 